\title{
Construction of Healthy and Palatable Diet for Low Socioeconomic Female Adults Using Linear Programming
}

\author{
Roslee Rajikan*, Nurul Izza Ahmad Zaidi*, Siti Masitah Elias", Suzana Shahar\%, Zahara Abd Manaf*, \\ Noor Aini Md Yusoff ${ }^{+}$ \\ *Dietetic Programme, School of Healthcare Sciences, Faculty of Health Sciences, \\ Universiti Kebangsaan Malaysia, 50300 Kuala Lumpur, Malaysia \\ E-mail:roslee@ukm.edu.my \\ ${ }^{\#}$ Financial Mathematics Programme, Faculty Sciences and Technology, \\ Universiti Sains Islam Malaysia, 71800 Nilai, Negeri Sembilan, Malaysia \\ E-mail:masitah@usim.edu.my \\ ${ }^{\%}$ Nutrition Programme, School of Healthcare Sciences, Faculty of Health Sciences, \\ Universiti Kebangsaan Malaysia, 50300 Kuala Lumpur, Malaysia \\ E-mail: suzanas@ukm.edu.my,zaharamanaf@ukm.edu.my
}
${ }^{+}$School of Nutrition and Dietetics, Faculty of Health Sciences, Universiti Sultan Zainal Abidin, 21300 Kuala Nerus, Terengganu, Malaysia ${ }^{+}$Institute for Community (Health) Development, Universiti Sultan Zainal Abidin, 21300, Kuala Nerus, Terengganu Malaysia E-mail:noorainimy@unisza.edu.my

\begin{abstract}
Differences in the socioeconomic profile may influences healthy food choices, particularly among individuals with low socioeconomic status. Thus, high-energy dense foods become the preferences compared to high nutritional content foods due to their cheaper price. The present study aims to develop healthy and palatable diet at the minimum cost based on Malaysian Dietary Guidelines 2010 and Recommended Nutrient Intake 2005 via linear programming. A total of 96 female adults from low socioeconomic families in Johor, South East Malaysia have been recruited for the present study. Anthropometric measurement; weight and height, socio-demographic information and 3-days food record have been collected from the subjects. In addition, data on food prices have also been collected. Then, a linear programming model has been developed to select the cheapest food combinations that could fulfil all the nutritional recommendations and palatable constraints in order to capture common dietary habit of the locals. Subsequently, healthy seven-days menus have been created using the optimal food servings estimated from the linear programming model. Dietary data have shown that the average energy intake among low-income adult women $(1871 \pm 317 \mathrm{kcal} / \mathrm{day})$ is less than the nutrient recommendation. Thus, from the linear programming analysis, the minimum food cost has been estimated at RM6.55 (2.15 USD) for the total energy intake of $2000 \mathrm{kcal}$ per day for a female adult which meets the recommendation of MDG 2010 and RNI 2005 . In conclusion, linear programming may be a useful tool to develop healthy and palatable diets at a minimal cost in managing dietary problems among low socioeconomic groups where food expenditure becomes an important restraining factor. Eventually, low socioeconomics female adults would improve their nutritional intake by making wiser food choices to meet all the nutritional requirements, which lead to healthier life.
\end{abstract}

Keywords - socioeconomic status; linear programming; constraints; healthy diet

\section{INTRODUCTION}

A healthy diet may improve productivity for all ages and it helps in the reduction and prevention of health problems such as chronic diseases and malnourishment from occurring [1]. Healthy diets are obtained by taking foods that contain nutrients in the recommended dose [2]. One's socioeconomic status is measured either by the income level, occupation or education. It has been revealed that socioeconomic status plays a major role in eating patterns and food choices. Thus, the socioeconomic status may be one of the factors that could cause unhealthy eating behaviour among people with low socioeconomic status [3].

Several studies have shown that energy-dense foods are foods that are commonly chosen by the low socioeconomic class due to their cheaper price [4]. These energy-dense foods are usually high in fat. Furthermore, diets among low socioeconomic individuals have been related to low consumption of fruits and vegetables. It has been explained 
that high nutritional value foods like fresh fruits and vegetables are expensive and as a result, cheaper food which has less nutritional value is favored among the low-income group [5]. Moreover, the low-income group is prone to consume cheaper foods which satisfy their hunger, rather than buying nutritious foods [6].

Low intake of fruits and vegetables among low socioeconomic adults has been reported in France, where it has been linked to psychosocial, educational, economic and material barriers [7]. This was probably due to a limited household budget and low nutritional knowledge in making healthy food choices. Besides, unhealthy eating patterns among the low-income group eventually would lead to health problems such as obesity, hypertension, heart diseases and diabetes. In the United States, the prevalence of overweight and obesity has been reported to be higher in low-income households and educational level [8], [9].

In Malaysia, based on the Malaysian Adult Nutrition Survey (MANS), most of female adults did not fulfill the recommendations for iron and calcium [10]. Despite the poor dietary habits, the prevalence of obesity and overweight was higher in women than men. An earlier research by [11] found that women were significantly more obese than men. In addition, the mean Body Mass Index (BMI) of female adults $\left(24.6 \mathrm{~kg} / \mathrm{m}^{2}\right)$ was significantly higher than the mean BMI among adults $\left(24.2 \mathrm{~kg} / \mathrm{m}^{2}\right)$. If this scenario is not prevented or overcome, it may lead to more complicated conditions especially among a vulnerable group like the lowincome people. The encouragement toward healthy balanced diet among the low-income group may improve their overall health status and eventually reduce the prevalence of chronic diseases in Malaysia.

Linear programming has been defined as a technique used in minimizing a set linear function of variables while relating multiple linear constraints. Basically, the technique is based on a mathematical approach [12]. Furthermore, it is one of the techniques that can be used in planning healthy diet menus where nutrient requirements can be achieved at the lowest cost [13]. Hence, this study aims to develop a healthy diet based on the Malaysian Dietary Guidelines (MDG) 2010 (NCCFN 2010) and Recommended Nutrient Intake (RNI) 2005 at a minimal cost and at the same time palatable for consumption among low socioeconomic female adults [14].

\section{MATERIAL AND METHOD}

Study design and sampling method: This study had been approved by Research Ethics Committee of Universiti Kebangsaan Malaysia (UKM) before two phases of data collection were conducted between March-April 2013. A cross-sectional study was done among 96 female adults at several low-cost flats at Taman Chendana in Pasir Gudang, Johor (South of Malaysia), which aged 19-59 years. The inclusion criterion was total household income < RM3000 (USD 932.40) per month. In the second phase, a survey was conducted to obtain the food prices which were used in the LP model to develop seven-days menus for $2000 \mathrm{kcal}$.

\section{A. Data Collection}

An interview-based questionnaire was distributed to subjects in the first phases to assess their socio-demographic profile and eating patterns. Anthropometric measurements including height and weight were measured using SECA Bodymeter model 208 and Tanita HD 309 respectively. Eating patterns of the subjects were assessed by three-day food records, where the subjects had to document their food intake for two days in a week and one over the weekend.

Based on the subjects eating pattern information, the price for each food items was obtained from the Ministry of Domestic Trade, Cooperative, and Consumerism (KPDNKK). The food prices were set in terms of price per serving size. Nutrient Composition of Malaysian Foods [15] was used to determine the nutrient content i.e. energy, macro-nutrients and some micro-nutrients such as calcium, iron, vitamin A, vitamin $\mathrm{C}$ and fibre for each food items. Both prices and nutrients were then fed into the LP model.

\section{B. Data Analysis}

All data in both sets of questionnaire were analyzed using Statistical Package for Social Sciences (SPSS) version 20.0. The results were presented descriptively for categorical data while means and standard deviation were calculated for continuous data. Nutritionist Pro software was used to assess dietary intake data prior to analysis by SPSS. Next, Excel Solver was utilized to develop the LP model in finding optimal food servings with the lowest cost. The model should have achieved the recommended dietary and nutrient requirements based on the Malaysian Dietary Guidelines (MDG 2010) (NCCFN 2010) and Recommended Nutrient Intake (RNI 2005) [14].

\section{Linear Programming Model}

The model used in LP was specified as follows

$$
\begin{gathered}
\text { Min } \mathrm{z}=\sum \mathrm{c}_{j} \mathrm{x}_{j} \\
\text { Subject to: } \mathrm{b}_{i} \leq \sum \mathrm{a}_{i j} \mathrm{x}_{\mathrm{j}} \leq \mathrm{b}_{i} \\
\mathrm{x}_{j} \geq 0
\end{gathered}
$$

The objective of the model was to minimize food cost, $z$ (in RM). The quantity of food item $j$ (in $\mathrm{kg}$ ) is represented as $X_{j} ; \mathrm{a}_{i j}$ denotes the amount of nutrient $i$ in one kilogram of food item $j ; C_{j}$ was the cost of a kilogram of food item $j ; b_{i}$ denotes the largest or smallest acceptable quantity of nutrient $i$. The constraints in the model for this study were MDG 2010 and RNI 2005. Palatability constraints were also included to ensure that the suggested menus were suited to the subjects' common food pattern. These constraints have been listed in Table 1.

There are seven food groups in MDG; cereals, grains, fruits, vegetables, meat/poultry, fish, legumes, milk and dairy products. The constraints included in the LP consist of the lower bound and upper bound values of MDG 2010 in terms of serving size. Energy, carbohydrate, protein, fat, calcium, iron, vitamin A, vitamin $\mathrm{C}$ and fibre were included as RNI constraints. The lower bound and upper bound of the nutrients were based on RNI 2005. In order to make the menus palatable; oils (palm oil and vegetable oils) and sugar were added where one serving of oils was equivalent to two teaspoons and one serving of sugar was defined as five teaspoons per day.

These constraints were placed together with prices and nutrient composition in the LP model. Once the software was run, the minimum cost and the selected raw food items were considered as a model. 
TABLE I

VALUES OF LOWER BOUND (LB) AND UPPER BOUND (UB) OF MDG 2010 , PALATABILITY AND RNI 2005 CONSTRAINTS

\begin{tabular}{|l|l|l|}
\hline Constraints & LB & UB \\
\hline MDG 2010 & 6 & 8 \\
\hline Cereals and grains (serving) & 2 & 3 \\
\hline Fruits (serving) & 3 & 5 \\
\hline Vegetables (serving) & 1 & 2 \\
\hline Meat/poultry (serving) & 1 & 3 \\
\hline Fish (serving) & 0.5 & 1 \\
\hline Legumes (serving) & 2 & 3 \\
\hline Milk and dairy products (serving) & & \\
\hline Palatability & 1 & 2 \\
\hline Vegetable oil (serving) & 1 & 2 \\
\hline Palm oil (serving) & 1 & 2 \\
\hline Sugar (serving) & \multicolumn{2}{|l|}{} \\
\hline RNI 2005 & 1800 & 2000 \\
\hline Energy (kcal) & 50.0 & 100.0 \\
\hline Protein $(\mathrm{g})$ & 275.0 & 300.0 \\
\hline Carbohydrate $(\mathrm{g})$ & 44.0 & 67.0 \\
\hline Fat $(\mathrm{g})$ & 800.0 & 2500.0 \\
\hline Calcium $(\mathrm{mg})$ & 29.0 & 45.0 \\
\hline Iron $(\mathrm{mg})$ & 500.0 & 3000.0 \\
\hline Vitamin A $(\mu \mathrm{g})$ & 70.0 & 2000.0 \\
\hline Vitamin C $(\mathrm{mg})$ & 20.0 & 30.0 \\
\hline Fiber $(\mathrm{g})$ & & \\
\hline
\end{tabular}

\section{RESULTS AND DISCUSSION}

\section{A. Socio-Demographic Data}

The socio-demographic characteristics of female adults are shown in Table 2. The mean age among 96 women subjects was 41.4 years where more than half of them were aged between 40 to 49 years. With regard to ethnicity, there were $97.9 \%$ Malays, $1.0 \%$ Indians and $1.0 \%$ from other ethnic races. Regarding the marital status, $86.5 \%$ were still married, $6.3 \%$ widowed and the remaining $7.3 \%$ were either divorced or separated. Based on the results, only $1.0 \%$ had never attended school, $18.8 \%$ completed primary schooling, $77.1 \%$, and $3.1 \%$ finished secondary schooling and university education respectively.

A total of $72.9 \%$ of the female adults were categorized as having low household income (< RM 2000) with the mean income of $1599.59 \pm 620.98$ per month according to the Department of Statistics, Malaysia (2007) [16]. The highest household income among the subjects was RM 3000, which was classified as the middle-class income. About $56.3 \%$ of the subjects distributed from RM 1001 to RM 2000 of their income for expenses on food, transportation, clothes and others, whereas the mean income distribution was RM $1291.71 \pm 479.41$

\section{B. Anthropometric Data}

The results from this study showed that $36.0 \%$ were under the category of normal BMI (BMI: $18.5 \mathrm{~kg} / \mathrm{m}^{2}$ to $24.9 \mathrm{~kg} / \mathrm{m}^{2}$ ), while $33.6 \%$ were having BMI more than $25 \mathrm{~kg} / \mathrm{m}^{2}$ which can be classified as either overweight or obese. These BMI categories are: underweight, normal, overweight and obese, based on WHO Expert Consultation 2004 [17].

\section{Dietary Pattern}

Table 3 shows the calories and nutrient intake with the percentage of subjects achieving RNI. The mean energy intake was $1871 \pm 317 \mathrm{kcal}$ which was lower than the RNI recommendation $(2180 \mathrm{kcal})$, and only $20.5 \%$ of the subjects met the RNI requirements. The mean percentage of the subject's carbohydrate intake was $52.1 \pm 4.9 \%$ which contributed about $52.0 \%$ of the total energy intake, while protein contributed about $15.0 \%$ and $30.0 \%$ of the total energy intake was contributed by fat. About a quarter of the subjects $(25.6 \%)$ met the requirement for carbohydrate; whereas for protein and fat, 39 subjects met the requirements.

In this study, no subject met the requirement for iron and folic acid, where intakes of $17.50 \pm 5.23 \mathrm{mg}$ and $97.52 \pm$ $34.84 \mu \mathrm{g}$ were recorded respectively. Other micronutrients intake such as calcium, zinc, B1, B2, B3 and vitamin C were also poor in the subjects' dietary habits. The only vitamin which was fulfilled by the subjects was vitamin A with a level of $17860 \pm 752.13 \mu \mathrm{g}$ reported.

\section{Development of Healthy and Palatable Menu}

Table 4 shows the comparison of food groups by the four LP models based on MDG 2010, palatability and RNI 2005 as the constraints for the total energy intake of $2000 \mathrm{kcal} /$ day. LP models should satisfy the upper and lower limit of the constraints which include the serving size of seven types of food groups (cereals and grains, fruits, vegetables, meat and poultry, fish, legumes, milk and dairy products) based on MDG 2010, the serving size of vegetable oils, palm oils and sugar as the palatability constraints and nine essential nutrients recommendation (macro-nutrient and micronutrient) based on RNI 2005.

In this study, it was found that all the constraint values for the four LP models were in the range of MDG, palatability and RNI constraints. Fat, calcium and vitamin $\mathrm{C}$ were in moderately acceptable limits while energy, iron, and fiber only reached the lower limit of the constraint values. Other nutrients such as carbohydrate $(\mathrm{CHO})$, protein, vitamin A and fiber reached the upper limit of the maximum acceptable value of RNI constraints for these nutrients. As a result, seven-day healthy and palatable menus have been developed according to MDG 2010 and RNI 2005 for low socioeconomic female adults in Taman Chendana.

The menus have been developed according to raw food materials at the lowest cost based on MDG, RNI and palatability constraints by using LP as shown in Table 5. It has been estimated that the minimal food cost for adult women in Taman Chendana is RM6.55 (2.15 USD) per day for total energy intake $2000 \mathrm{kcal}$. Furthermore, the minimal cost had considered foods that meet nutrient recommendations with the palatability and eating habits of female adults in Taman Chendana are taken into account.

The present study shows a healthy and palatable menu at minimal cost for low socioeconomic female adults through the adoption of LP can be developed. Besides, the menu is able to meet the daily nutritional requirements based on MDG 2010 and RNI 2005. This LP model has also been used widely in the United States where it has helped low socio-economic households achieved nutritional recommendations at minimal cost based on Dietary Guidelines. Furthermore, including the general nutrient recommendations into low socio-economic, female adults' practice was a challenge as the population eating habits, food prices and diet costs need to be taken into consideration [18]. 
The dietary patterns of low-income female adults in Taman Chendana showed that the intake of several micronutrients such as iron, calcium, and zinc did not meet the nutritional requirement that has been recommended. Limited food expenses among low-income female adults have made them unable to afford healthy foods such as fruits and vegetables which are high in nutrient content [19]. Lack of iron, calcium and zinc intake among the subjects was probably due to their tendency to choose non-green vegetables such as carrots, tomatoes, and cabbage that are usually high in vitamin A. Furthermore, most low-income consumers prefer to buy foods which are sources of vitamin A [20].

TABLE III

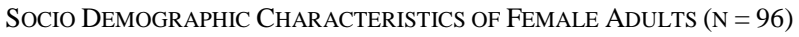

\begin{tabular}{|c|c|c|c|c|}
\hline Characteristics & $\mathbf{N}$ & $\%$ & Mean & Range \\
\hline \multicolumn{5}{|l|}{ Age (years) } \\
\hline $30-39$ & 38 & 39.6 & \multirow{3}{*}{$41.42 \pm 4.35$} & \multirow{3}{*}{$32-51$} \\
\hline $40-49$ & 54 & 56.3 & & \\
\hline$\geq 50$ & 4 & 4.2 & & \\
\hline \multicolumn{5}{|l|}{ Ethnic } \\
\hline Malay & 94 & 97.9 & & \\
\hline Indian & 1 & 1.0 & & \\
\hline Others & 1 & 1.0 & & \\
\hline \multicolumn{5}{|l|}{ Marital status } \\
\hline Married & 83 & 86.5 & & \\
\hline Widowed & 6 & 6.3 & & \\
\hline Divorced/separated & 7 & 7.3 & & \\
\hline \multicolumn{5}{|l|}{ Educational status } \\
\hline No formal education & 1 & 1.0 & & \\
\hline Primary school & 18 & 18.8 & & \\
\hline Secondary school & 74 & 77.1 & & \\
\hline Tertiary education & 3 & 3.1 & & \\
\hline \multicolumn{5}{|l|}{ Household size } \\
\hline$<3$ & 1 & 1.0 & & \multirow{4}{*}{$2-11$} \\
\hline $3-6$ & 59 & 61.5 & & \\
\hline $7-10$ & 35 & 36.5 & & \\
\hline$\geq 11$ & 1 & 1.0 & & \\
\hline \multicolumn{5}{|l|}{ Household income (RM) } \\
\hline$<2000$ & 70 & 72.9 & \multirow{3}{*}{$1599.59 \pm 620.98$} & \multirow{3}{*}{$150.00-3000.00$} \\
\hline $2000-3999$ & 26 & 27.1 & & \\
\hline$\geq 4000$ & 0 & 0 & & \\
\hline \multicolumn{5}{|c|}{ Household expenditures (RM) } \\
\hline$\leq 1000$ & 35 & 36.5 & \multirow{3}{*}{$1291.71 \pm 479.41$} & \multirow{3}{*}{$567.00-2690.00$} \\
\hline $1001-2000$ & 54 & 56.3 & & \\
\hline $2001-3000$ & 7 & 7.3 & & \\
\hline
\end{tabular}

TABLE IIIII

CAlories and Nutrient Intake With The Percentage of Subjects AChieving RNI ( $=39$ )

\begin{tabular}{|l|l|l|}
\hline Nutrients & Mean intake & Percentage of subjects achieving RNI \\
\hline Energy $(\mathrm{kcal})$ & $1871 \pm 317$ & 20.5 \\
\hline Protein $(\mathrm{g})$ & $70.35 \pm 13.07$ & 92.3 \\
\hline Energy percentage from carbohydrate $(\%)$ & $52.11 \pm 4.94$ & 25.6 \\
\hline Energy percentage from protein $(\%)$ & $15.45 \pm 1.66$ & 100 \\
\hline Energy percentage from fat $(\%)$ & $32.43 \pm 4.75$ & 100 \\
\hline Calcium $(\mathrm{mg})$ & $528.89 \pm 266.25$ & 12.8 \\
\hline Iron $(\mathrm{mg})$ & $17.50 \pm 5.23$ & 0 \\
\hline Zinc $(\mathrm{mg})$ & $3.53 \pm 1.16$ & 15.4 \\
\hline Thiamine $(\mathrm{mg})$ & $0.72 \pm 0.33$ & 10.3 \\
\hline Riboflavin $(\mathrm{mg})$ & $1.09 \pm 0.42$ & 33.3 \\
\hline Niacin $(\mathrm{mg} \mathrm{NE})$ & $10.04 \pm 3.26$ & 15.4 \\
\hline Folic acid $(\mu \mathrm{g})$ & $97.52 \pm 34.84$ & 0 \\
\hline Vitamin C $(\mathrm{mg})$ & & \\
\hline Vitamin $\mathrm{A}(\mu \mathrm{g})$ & $58.50 \pm 40.66$ & 25.6 \\
\hline
\end{tabular}


TABLE IV

COMPARISON OF FOOD GROUPS BY THE FOUR MODELS WITH MDG, PALATABILITY AND RNI CONSTRAINTS FOR 2000 KCAL

\begin{tabular}{|c|c|c|c|c|c|}
\hline Constraints & LB & UB & Model I & Model II & Model III \\
\hline \multicolumn{6}{|l|}{ MDG 2010} \\
\hline Cereals and grains (serving) & 6 & 8 & 6.5 & 6 & 6 \\
\hline Fruits (serving) & 2 & 3 & 3 & 3 & 2 \\
\hline Vegetables (serving) & 3 & 5 & 3 & 4 & 4 \\
\hline Meat/poultry (serving) & 1 & 2 & 1.5 & 1 & 1 \\
\hline Fish (serving) & 1 & 3 & 1 & 2 & 2 \\
\hline Legumes (serving) & 0.5 & 1 & 1 & 1 & 1 \\
\hline Milk and dairy products (serving) & 2 & 3 & 2 & 2 & 3 \\
\hline Palatability & & & 2 & 2 & 2 \\
\hline Vegetable oil (serving) & 1 & 2 & 1 & 1 & 1 \\
\hline Palm oil (serving) & 1 & 2 & 1 & 1 & 1 \\
\hline Sugar (serving) & 1 & 2 & & & \\
\hline \multicolumn{6}{|l|}{ RNI 2005} \\
\hline Energy (kcal) & 1800 & 2000 & 2000 & 2000 & 2000 \\
\hline Protein $(\mathrm{g})$ & 50.0 & 100.0 & 100.0 & 100.0 & 100.0 \\
\hline Carbohydrate (g) & 275.0 & 300.0 & 300.0 & 300.0 & 300.0 \\
\hline Fat $(\mathrm{g})$ & 44.0 & 67.0 & 54.2 & 50.4 & 51.2 \\
\hline Calcium (mg) & 800.0 & 2500.0 & 1243.8 & 1053.0 & 1115.9 \\
\hline Iron (mg) & 29.0 & 45.0 & 29.0 & 29.0 & 29.0 \\
\hline Vitamin A $(\mu \mathrm{g})$ & 500.0 & 3000.0 & 3000.0 & 3000.0 & 3000.0 \\
\hline Vitamin C (mg) & 70.0 & 2000.0 & 470.2 & 650.4 & 649.3 \\
\hline Fiber $(\mathrm{g})$ & 20.0 & 30.0 & 20.0 & 30.0 & 30.0 \\
\hline Cost (RM) & & & 6.55 & 8.91 & 10.44 \\
\hline
\end{tabular}

TABLE V

Development of SeVen-Day Menu Planning for 2000 KCAl with Minimal Cost PeR Day

\begin{tabular}{|c|c|c|c|c|c|c|c|}
\hline Meals & Day 1 & Day 2 & Day 3 & Day 4 & Day 5 & Day 6 & Day 7 \\
\hline Breakfast & $\begin{array}{l}\text { Fried, noodles } \\
\text { Tea }\end{array}$ & $\begin{array}{l}\text { 'Kampong' } \\
\text { Fried rice } \\
\text { Tea }\end{array}$ & $\begin{array}{l}\text { 'Kampong' } \\
\text { Fried rice } \\
\text { Tea with low- } \\
\text { fat milk } \\
\text { Banana }\end{array}$ & $\begin{array}{l}\text { Noodles, soup } \\
\text { Tea }\end{array}$ & $\begin{array}{l}\text { Pancake, } \\
\text { wheat } \\
\text { Tea }\end{array}$ & $\begin{array}{l}2 \text { pieces white } \\
\text { bread } \\
1 / 4 \text { teaspoon of } \\
\text { margarine } \\
1 \text { glass of } \\
\text { low-fat milk }\end{array}$ & $\begin{array}{l}\text { Fried, noodles } \\
\text { Tea }\end{array}$ \\
\hline Morning tea & $\begin{array}{l}2 \text { pieces of } \\
\text { sardine bun } \\
\text { Tea }\end{array}$ & $\begin{array}{l}2 \text { pieces of } \\
\text { sardine } \\
\text { sandwich } \\
\text { Tea with low- } \\
\text { fat milk }\end{array}$ & $\begin{array}{l}1 \text { glass of full } \\
\text { cream milk }\end{array}$ & $\begin{array}{l}6 \text { pieces } \\
\text { cekodok } \\
\text { pisang } \\
\text { Tea with low- } \\
\text { fat milk }\end{array}$ & $\begin{array}{l}2 \text { pieces } \\
\text { toasted bread } \\
1 \text { glass of } \\
\text { low-fat milk }\end{array}$ & $\begin{array}{l}\text { Pancake, } \\
\text { wheat } \\
\text { Tea }\end{array}$ & $\begin{array}{l}2 \text { pieces of } \\
\text { toasted bread } \\
1 \text { glass of } \\
\text { low-fat milk }\end{array}$ \\
\hline Lunch & $\begin{array}{l}\text { Cooked, rice } \\
\text { Sardine, fried } \\
\text { in chili } \\
\text { Spinach, in } \\
\text { water } \\
\text { Guava }\end{array}$ & $\begin{array}{l}\text { Cooked, rice } \\
\text { Sardine, curry } \\
\text { Kerabu tau } \\
\text { geh } \\
\text { Pineapple }\end{array}$ & $\begin{array}{l}\text { Cooked, rice } \\
\text { Indian } \\
\text { mackerel, } \\
\text { cooked in } \\
\text { tamarind } \\
\text { String bean, } \\
\text { fried } \\
\text { Guava }\end{array}$ & $\begin{array}{l}\text { Cooked, rice } \\
\text { Ikan kembong } \\
\text { kecil masak } \\
\text { singgang } \\
\text { String bean, } \\
\text { fried } \\
\text { Guava }\end{array}$ & $\begin{array}{l}\text { Cooked, rice } \\
\text { Catfish, } \\
\text { cooked in } \\
\text { coconut milk } \\
\text { (grilled) } \\
\text { Sambal jawa } \\
\text { Sayur campur } \\
\text { goreng } \\
\text { Guava }\end{array}$ & $\begin{array}{l}\text { Cooked, rice } \\
\text { Hairtail scad, } \\
\text { fried in chili } \\
\text { Sayur capcai } \\
\text { goreng } \\
\text { Guava }\end{array}$ & $\begin{array}{l}\text { Cooked, rice } \\
\text { Hairtail scad, } \\
\text { fried } \\
\text { Sayur masak } \\
\text { lodeh } \\
\text { Guava }\end{array}$ \\
\hline Afternoon tea & $\begin{array}{l}2 \text { pieces of } \\
\text { white bread } \\
1 \text { glass of full } \\
\text { cream milk }\end{array}$ & $\begin{array}{l}\text { 2.pieces of } \\
\text { white bread } \\
1 \text { glass of full } \\
\text { cream milk }\end{array}$ & $\begin{array}{l}\text { Pancake, } \\
\text { wheat } \\
\text { Tea }\end{array}$ & $\begin{array}{l}1 \text { glass of full } \\
\text { cream milk }\end{array}$ & $\begin{array}{l}1 \text { glass of full } \\
\text { cream milk }\end{array}$ & $\begin{array}{l}1 \text { glass of full } \\
\text { cream milk }\end{array}$ & $\begin{array}{l}1 \text { glass of full } \\
\text { cream milk }\end{array}$ \\
\hline Dinner & $\begin{array}{l}\text { Cooked, rice } \\
\text { Chicken } \\
\text { breast, cooked } \\
\text { in soy sauce } \\
\text { Egg } \\
\text { Bean sprouts } \\
\text { with tofu, } \\
\text { cooked in } \\
\text { coconut milk } \\
\text { Pineapple }\end{array}$ & $\begin{array}{l}\text { Noodles, tom } \\
\text { yam } \\
\text { Guava }\end{array}$ & $\begin{array}{l}\text { Noodles, soup } \\
\text { Tea }\end{array}$ & $\begin{array}{l}\text { Cooked, rice } \\
\text { Quail egg, } \\
\text { fried in chili } \\
\text { Swamp } \\
\text { cabbage, fried } \\
\text { Guava }\end{array}$ & $\begin{array}{l}\text { Cooked, rice } \\
\text { Hairtail scad, } \\
\text { grilled } \\
\text { Pencicah } \\
\text { Swamp } \\
\text { cabbage, fried } \\
\text { Guava }\end{array}$ & $\begin{array}{l}\text { Cooked, rice } \\
\text { Catfish, } \\
\text { cooked in } \\
\text { chili } \\
\text { Swamp } \\
\text { cabbage, fried } \\
\text { Guava }\end{array}$ & $\begin{array}{l}\text { Cooked, rice } \\
\text { Fried Catfish, } \\
\text { Swamp } \\
\text { cabbage fried } \\
\text { Guava }\end{array}$ \\
\hline $\begin{array}{l}\text { Food cost per } \\
\text { day (RM) }\end{array}$ & 6.55 & 6.55 & 8.91 & 8.91 & 10.44 & 10.44 & 10.44 \\
\hline
\end{tabular}


Moreover, most of the subjects preferred not to consume milk and dairy products. This has to be the reason, why the dietary analysis showed that there was a lack of calcium consumption. According to [10], the mean intake of iron and calcium among Malaysian female adults has been reported to be lower than the nutritional requirements. Unfortunately, these micronutrients may be found in healthy food such as green vegetables, fruits, milk and dairy products, which are expensive for the low-income groups. This result was consistent with the study performed by [21], which reported that most of low socio-economic adults tend to buy unhealthy food items like energy-dense foods and processed foods which have poor nutritional content.

Thus, the LP model has been used in this study in order to overcome dietary problems among low-income female adults to achieve a healthy diet. The application of this LP model was important in identifying nutritionally adequate diet at a minimal cost, where the collection of local food prices is linearly related to food weight [12]. Hence, through the adoption of LP model, the minimum food cost was RM6.55 (2.15 USD) per person per day. Furthermore, a variety of meals could be prepared and presented differently for seven days which include six types of meals from breakfast to supper. All these menus meet the daily nutritional requirement for adults at a minimal cost only.

However, there were a few limitations in developing the model using the LP analysis. We had to exclude several food items in order to generate the second and third cheapest optimal food choice to avoid repetition of food choices. Therefore, we only ran the program three times to find the minimum food cost and choices. As we made more exclusion, the cost continued to rise and appeared unaffordable for the low socioeconomic groups. Furthermore, there were too many constraints and expectations for the food items which resulted in making the model become unfeasible. Therefore, more lists of food items should be included in the model to reduce the limitations in future studies.

This study has revealed that healthy and palatable menus can be developed for low socioeconomic female adults by using the LP model at a minimal cost. In addition, poor dietary [22], [23] intake may be improved using this model where it follows the MDG, RNI and palatability constraints to meet the nutritional requirements.

\section{ACKNOWLEDGMENT}

The authors would like to thank all of the subjects for their cooperation and support toward this research project.

\section{REFERENCES}

[1] A. Darko, B. Allen, J. Mazunda, R. Rahimzai, and C. L. Dobbins, "Cost-minimizing food budgets in Ghana," in Proc. AAEA'10 and AEASA'10, 2010, p. 1.

[2] M. Maillot, A. Drewnowski, F. Vieux, and N. Darmon, "Quantifying the contribution of foods with unfavourable nutrient profiles to nutritionally adequate diets," British Journal of Nutrition, vol. 105, pp. 1133-1137, Apr. 2011.

[3] P. J. Veugelers, A. M. Yip, and G. Kephart, "Proximate and contextual socioeconomic determinants of mortality: Multilevel approaches in a setting with universal health care coverage," American Journal of Epidemiology, vol. 154, pp. 725-732, Oct. 2001.
[4] G. Cuco, V. Arija, C. Marti-Henneberg, and J. Fernandez-Ballart, "Food and nutritional profile of high energy density consumers in an adult Mediterranean population," European Journal of Clinical Nutrition, vol. 55, pp. 192-199, Mar. 2001.

[5] K. Giskes, G. Turrell, C. Patterson, and B. Newman, "Socioeconomic differences among Australian adults in consumption of fruit and vegetables and intakes of vitamins A, C and folate," Journal of Human Nutrition and Dietetics, vol. 15, pp. 375-385, Oct. 2002.

[6] M. Glanz, E. Basil, J. Maibach Goldberg, and D. Snyder, "Why Americans eat what they do: Taste, nutrition, cost, convenience and weight control concerns as influences on food consumption," Journal of the American Dietetic Association, vol. 98, pp. 1118-1126, Oct. 1998.

[7] N. Darmon, E. L. Ferguson, and A. Briend, "Impact of a cost constraint on nutritionally adequate food choices for French women: An analysis by linear programming," Journal of Nutrition Education and Behavior, vol. 38, pp. 82-90, Apr. 2006.

[8] Y. J. Mi, B. Zhang, H. J. Wang, J. Yan, W. Han, J. Zhao, D. W. Liu, and Q. B. Tian, "Prevalence and secular trends in obesity among chinese adults, 1991-2011," American Journal of Preventive Medicine, vol. 49, pp. 661-669, Nov. 2015.

[9] S. Paeratakul, J. Lovejoy, D. Ryan, and G. Bray, "The relation of gender, race and socioeconomic status to obesity and obesity comorbidities in a sample of US adults," International Journal of Obesity and Related Metabolic Disorders, vol. 26, pp. 1205-1210, Sep. 2002.

[10] K. Mirnalini, M. S. Zalilah, M. Y. Safiah, A. Tahir, H. M. Siti, R. D. Siti, Z. M. Khairul, H. S. Mohd, and H. Normah, "Energy and nutrient intakes: Findings from the Malaysian Adult Nutrition Survey (MANS)," Malaysian Journal of Nutrition, vol. 14, pp. 1-24, Mar. 2008.

[11] M. Y. Azmi, R. Junidah, A. S. Mariam, M. Y. Safiah, and S. Fatimah, A. K. Norimah, B. K. Poh, M. Kandiah, M. S. Zalilah, W. M. W. A. Manan and M. D. Haslinda, "Body Mass Index (BMI) of adults: Findings of the Malaysian Adult Nutrition Survey (MANS)," Malaysian Journal of Nutrition, vol. 15, pp. 97-119, Sep. 2009.

[12] A. Briend, E. Ferguson, and N. Darmon, "Local food price analysis by linear programming: A new approach to assess the economic value of fortified food supplements," Food and Nutrition Bulletin, vol. 22, pp. 184-189, Jun. 2001.

[13] A. Parlesak, I. Tetens, J. D. Jensen, S. Smed, M. G. Blenkuš, M Rayner, N. Darmon, and A. Robertson, "Use of linear programming to develop cost-minimized nutritionally adequate health promoting food baskets," PLoS One, vol. 11, pp. 1-19, Oct. 2016.

[14] H. C. Koo, B. K. Poh, S. T. Lee, K. H. Chong, M. C. Bragt, R. A. Talib, and SEANUTS Malaysia Study Group, "Are Malaysian children achieving dietary guideline recommendations?," AsiaPacific Journal of Public Health, pp. 1-13, Apr. 2016.

[15] M. Fairulnizal, M. K. Norhayati, A. Zaiton, A. H. Norliza, S. Rusidah, A. R. Aswir, M. Suraiami, M. Naeem, A. Jo-Lyn, J. Mohd Azerulazree, and B. Vimala, "Nutrient content in selected commercial rice in Malaysia: An update of Malaysian food composition database," International Food Research Journal, vol. 22, Apr. 2015.

[16] Department of Statistic Malaysia. (2009) Pendapatan isi rumah bulanan purata, penengah dan kadar pertumbuhan tahunan purata mengikut negeri Malaysia 2007 dan 2009. [Online]. Available: http://www.statistics.gov.my/portal/download_household/files/house hold/2009/Jadual1.pdf

[17] WHO Expert Consultation, "Appropriate body-mass index for Asian populations and its implications for policy and intervention strategies," Lancet, vol. 363, pp. 157-163, Jan. 2004.

[18] G. Masset, P. Monsivais, M. Maillot, N. Darmon, and A Drewnowski, "Diet optimization methods can help translate dietary guidelines into a cancer prevention food plan," Journal of Nutrition, vol. 139, pp. 1541-1548, Aug. 2009.

[19] L. Wellard, M. Havill, C. Hughes, W. L. Watson, and K. Chapman, "Energy-dense fast food products cost less: An observational study of the energy density and energy cost of Australian fast foods," Australian and New Zealand Journal of Public Health, vol. 39, pp. 544-545, Dec. 2015

[20] J. R. Bogard, S. H. Thilsted, G. C. Marks, M. A. Wahab, M. A. Hossain, J. Jakobsen, and J. Stangoulis, "Nutrient composition of important fish species in Bangladesh and potential contribution to 
recommended nutrient intakes," Journal of Food Composition and Analysis, vol. 42, pp. 120-133, Sep. 2015.

[21] A. Drewnowski and S. E. Specter, "Poverty and obesity: The role of energy density and energy costs," American Journal of Clinical Nutrition, vol. 79, pp. 6-16, Jan. 2004

[22] M. R. Abdullah, A. B. H. M. Maliki, R. M. Musa, N. A. Kosni, and H. Juahir, "Intelligent prediction of soccer technical skill on youth soccer player's relative performance using multivariate analysis and artificial neural network techniques," International Journal on
Advanced Science, Engineering and Information Technology, vol. 6, pp. 668-674, Oct. 2016

[23] S. Sulaiman, Z. A. Manaf, and M. R. Shahril, "Compliance to dietary counselling in controlling blood lipid and its barriers among dyslipidemic individuals," International Journal on Advanced Science, Engineering and Information Technology, vol. 6, pp. 697702 , Oct. 2016 